Ewa BUJWID-KUREK

Uniwersytet Jagielloński

ewa.bujwid-kurek@uj.edu.pl

\title{
PAŃSTWA O PROWENIENCJI JUGOSŁOWIAŃSKIEJ W PROCESIE ROZSZERZANIA UNII EUROPEJSKIEJ - REFLEKSJA POLITOLOGICZNA
}

ABSTRACT Post-Yugoslav states in the EU enlargement process - political reflection The main research goal of the article is the assessment of the degree of preparation Post-Yugoslav state for accession to the European Union. The analysis included states such as the Republic of Macedonia, Bosnia and Herzegovina, the Republic of Serbia, Montenegro and the Republic of Kosovo (in the order of announcing independence). An in-depth analysis confirms that the Republic of Macedonia, the Republic of Serbia and the Republic of Montenegro have the status of EU candidate states. The other two: Bosnia and Herzegovina and the Republic of Kosovo have the status of potential EU candidates. According to the European Commission, the Republic of Serbia and Montenegro have the highest chances of EU membership, probably in 2025. There are many problems that the Post-Yugoslav states are struggling with. These states have to "learn" democracy. It should underline that there are still unregulated matters as like as rule of law (implementation in practice), corruption or crime (including organized crime) as well.

Keywords: EU enlargement process, EU membership, Post-Yugoslav states

Słowa kluczowe: proces rozszerzenia UE, członkostwo w UE, państwa o proweniencji jugosłowiańskiej 
Rozszerzenie stuży realizacji strategicznych interesów Unii Europejskiej dotyczacych stabilności, bezpieczeństwa i zapobiegania konfliktom. Przyczynia sie ono do zwiększania dobrobytu i możliwości wzrostu gospodarczego [... $]^{1}$.

\section{WPROWADZENIE}

Kraje byłej Jugosławii, mierzące się z bytem jako samodzielne państwa, profilując swoją politykę wewnętrzną i zewnętrzną, znalazły się w obliczu wielu nowych wyzwań. Jednym z nich była integracja europejska. Wszystkie państwa wywodzące się z multietnicznej federacji jugosłowiańskiej: Republika Słowenii, Republika Chorwacji, Republika Macedonii, Bośnia i Hercegowina, Republika Serbii, Czarnogóra i Republika Kosowa za swój priorytet uznały uzyskanie statusu pełnoprawnego członka Unii Europejskiej. By zrealizować ten cel, każde państwo musi spełnić ściśle określone wymagania (zarówno polityczne, jak i gospodarcze), wynikające z kryteriów kopenhaskich. Unia Europejska, posługując się narzędziem screeningu, precyzyjnie monitoruje stopień przygotowania do członkostwa każdego państwa, analizując i oceniając osobno każdy przypadek.

Spośród państw pojugosłowiańskich pełnoprawnymi członkami Unii Europejskiej są Republika Słowenii (od 1 maja 2004 r.) i Republika Chorwacji (od 1 lipca 2013 r.). Pozostałe państwa: Republika Macedonii, Bośnia i Hercegowina, Republika Serbii, Czarnogóra i Republika Kosowa wciąż jeszcze oczekują na uzyskanie statusu pełnoprawnego członka UE2 . Jakie przeszkody w staraniach o członkostwo w Unii Europejskiej napotykają te państwa? Dlaczego w interesie UE jest rozszerzanie o coraz to nowe państwa, w tym rekrutujące się z niezwykle konfliktogennego obszaru bałkańskiego? Nadto ciekawe wydaje się ustalenie katalogu wspólnych problemów, z którymi zmagają się państwa zainteresowane integracją w ramach Unii Europejskiej, oraz tego, czy istnieją jakieś problemy osobliwe, szczególnie trudne do wyeliminowania, dotyczące państw pojugosłowiańskich.

Za główny cel badawczy niniejszych rozważań przyjęto próbę odpowiedzi na postawione wyżej pytania, które - zwłaszcza w analizie politologicznej - wydają się bardzo istotnymi problemami badawczymi. W toku rozważań wykorzystane zostaną metody badawcze właściwe dla nauk społecznych, w tym szczególnie metoda opisowa, przyczynowo-skutkowa i komparatystyczna, oraz oceny będące wynikiem monitorowania aktualnej sytuacji w państwach poddanych analizie. W toku wywodu zachowany zostanie porządek wedle kolejności ogłaszania aktów niepodległości przez państwa. Dlatego najpierw zostanie poddana analizie Republika Macedonii (samodzielne państwo od 17 października 1991 r.), następnie Bośnia i Hercegowina, Republika

Komisja Europejska, 2009 - rok Batkanów Zachodnich, Bruksela, 5 XI 2008, IP/08/1638, [online] http://europa.eu/rapid/press-release_IP-08-1638_pl.htm, 5 V 2018.

2 Na ten temat szerzej zob. E. Bujwid-Kurek, „Nieunijne” państwa pojugostowiańskie w obliczu integrujacej się Europy - uwag kilka, „Studia Politologiczne” 2018, vol. 47, s. 169-186. 
Serbii, Czarnogóra i, jako ostatnia, Republika Kosowa. Pominięto państwa posiadające pełnoprawne członkostwo w Unii Europejskiej: Republikę Słowenii i Republikę Chorwacji.

Warto zauważyć, iż celem strategicznym o kluczowym dla Unii Europejskiej znaczeniu jest obecnie przyjęcie do swojego grona państw bałkańskich, w tym pojugosłowiańskich. O członkostwo w Unii może ubiegać się wyłącznie to państwo europejskie, które spełnia ściśle określone warunki: wyraża szacunek dla wartości demokratycznych, posiada stabilne instytucje demokratyczne gwarantujące rządy prawa i przestrzeganie prawa mniejszości narodowych oraz etnicznych, ma sprawnie funkcjonującą gospodarkę oraz zdolność do podejmowania i wykonywania obowiązków wynikających z członkostwa w Unii Europejskiej³. W kontekście podjętej problematyki warto zauważyć, iż każde z wziętych tu pod uwagę państw, w pełni świadome swej powinności w kwestii ubiegania się o członkostwo w UE, podejmuje działania zgodnie z procedurą akcesji przewidzianą w art. $49 \mathrm{TUE}^{4}$.

\section{OCENA PARTYCYPACJI W PROCESIE ROZSZERZANIA UNII EUROPEJSKIEJ ( STAN NA MAJ 2018)}

\subsection{Republika Macedonii}

Republika Macedonii (Była Jugosłowiańska Republika Macedonii) ${ }^{5}$ wniosek o członkostwo w UE złożyła w marcu 2004 r. Do grona państw kandydujących została włączona ponad rok później, bo w grudniu 2005 r. Od 2008 r. czyniono starania o rozpoczęcie negocjacji akcesyjnych, każdorazowo odrzucane, mimo że Komisja Europejska w październiku 2013 r. po raz kolejny je rekomendowała. Dopiero w 2017 r. KE zaleciła rozpoczęcie negocjacji akcesyjnych. Rodzi się więc pytanie: dlaczego tak długo odwlekano tę - jakże ważną dla Macedonii - decyzję? Głównym powodem, dla którego przez długi czas nie rozpoczynano negocjacji akcesyjnych z Republiką Macedonii, był

Batkany Zachodnie: Kolejny kierunek rozszerzenia Unii Europejskiej?, [online] www.europarl.europa. eu/news/pl/headlins/world/20180126S5094113/ball, 23 III 2018. Zob. też: R. Zawistowska, Miejsce Batkanów Zachodnich w polityce Unii Europejskiej, ,Annales Universitatis Paedagogicae Cracoviensis. Studia Politologica" 2012, nr 7, s. 200-219.

4 Art. 49 TUE Wniosek o członkostwo w Unii: Każde państwo europejskie, które szanuje wartości, o których mowa w artykule 2 i zobowiąuje sięje wspierać może ztożyć wniosek o cztonkostwo w Unii. O wniosku tym informuje się Parlament Europejski i parlamenty narodowe. Państwo ubiegające się o cztonkostwo kieruje swój wniosek do Rady, która stanowi jednomyślnie po zasięgnięciu opinii Komisji oraz po otrzymaniu zgody Parlamentu Europejskiego, udzieloną większościa gtosów jego cztonków. Brane pod uwagę kryteria kwalifikacji uzgodnione przez Rade Europejska. Zob. Traktat o Unii Europejskiej, stan prawny na 9 V 2018, Dz.U. UE 2004, 90.864/30, [online] www.arslege.pl/traktat-o-unii-europejskiej/k78, 9 V 2018.

5 W rejestrze ONZ i Unii Europejskiej widnieje pod nazwą Former Yogoslav Republic of Macedonia (FYROM). Zob. też: R. Podgórzańska, Perspektywy integracji państw pojugostowiańskich z Unią Europejska, „Rocznik Integracji Europejskiej” 2010, nr 4, s. 111. 
- i nadal pozostaje - nierozstrzygnięty spór z Grecją o nazwę państwa „Macedonia”. Jedną z przeszkód stojących na drodze do rozpoczęcia negocjacji stało się także nieporozumienie Macedonii z Bułgarią o projekt traktatu międzypaństwowego. W sprawozdaniach Komisji Europejskiej i rezolucjach Parlamentu Europejskiego z lat 2015, 2016 i 2017 zwraca się uwagę na problemy, z którymi zmaga się przygotowująca się do pełnoprawnego członkostwa w UE Macedonia. Są wśród nich: przestępczość, korupcja, utrwalone silne struktury mafijne, trudności w prowadzeniu dialogu politycznego i konsultacji społecznych, brak reformy policji i sądownictwa oraz reformy administracji publicznej. Zwraca się także uwagę na nieodpowiednio prowadzoną politykę państwa w dziedzinie zatrudnienia i rynku pracy. Poważny niepokój budzą też przypadki łamania prawa podczas wyborów, szczególnie parlamentarnych, zwłaszcza na terenach zamieszkałych przez szacowaną na ok. 24\% mniejszość albańską. Podkreśla się również konieczność kontynuowania realizacji postanowień z porozumienia z Pržino ${ }^{7}$ oraz przywiązuje się dużą wagę do postępów we wdrażaniu pilnych reform w obszarach priorytetowych.

\subsection{Bośnia i Hercegowina}

Bośnia i Hercegowina (BiH) usamodzielniła się jako czwarta republika federacji jugosłowiańskiej, tworząc dwupodmiotową strukturę państwa. Dnia 25 listopada 2005 r. rozpoczęła negocjacje z UE, a trzy lata później, 16 czerwca 2008 r., wynegocjowano i podpisano Układ o stabilizacji i stowarzyszeniu. Jednak jego wejście w życie zostało wstrzymane, przede wszystkim z powodu niewykonania orzeczenia Europejskiego Trybunału Praw Człowieka. Warto jednak pamiętać, że już w 2000 r. Bośnia i Hercegowina wraz z Komisją Europejską utworzyła Konsultacyjną Grupę Roboczą; Komisja wyznaczyła dla tego kraju powinności o kluczowym znaczeniu, które musi on wypełnić, by zostać przyjętym do $\mathrm{UE}^{8}$.

Obecnie obowiązuje jedynie umowa przejściowa dotycząca handlu i wszystkich kwestii z tym związanych. Bośnia i Hercegowina nie ma statusu oficjalnego kandydata do Unii Europejskiej, nie rozpoczęto też negocjacji o członkostwo; jest potencjalnym kandydatem, a data jej wejścia do UE jest wciąż jeszcze bliżej nieokreślona. Główne zastrzeżenia kierowane pod adresem BiH są związane z niestabilnością państwa rozumianego jako polityczna organizacja społeczeństwa oraz z zagrożeniami generowanymi jego

6 Dwa państwa członkowskie UE: Grecja i Cypr są nieprzejednane w kwestii używania nazwy państwa „Macedonia” i zapowiadają zablokowanie wejścia Republiki Macedonii do Unii Europejskiej.

Dzięki mediacji UE 15 VII 2015 r. wypracowano w Macedonii porozumienie między ówczesnym rządem a opozycją, umożliwiające wyjście tego kraju z głębokiego kryzysu. Porozumienie to zostało podpisane przez cztery główne partie polityczne; zdecydowano w nim o przyspieszonych wyborach, które miały się odbyć w kwietniu $2016 \mathrm{r}$.

8 D. Lopandić, J. Kronja, Regionalne inicijative i multilateralna saradnjana Balkanu, Beograd 2010, s. 221. Zob. też: D. Wybranowski, Bośnia i Hercegowina wobec Unii Europejskiej - trudna droga ku stowarzyszeniu. Problemy i wyzwania polityki UE na Batkanach Zachodnich na poczattku XXI wieku, „Wrocławskie Studia Politologiczne” 2009, nr 10, s. 220-235. 
problematyczną strukturą. Szczególną uwagę zwraca się na tendencje separatystyczne Serbów zamieszkujących Republikę Serbską w Bośni i Hercegowinie. Poważny problem stwarza też istniejący podział państwa i brak woli porozumienia między ludnością je zamieszkującą: Chorwatami, Serbami, Bośniakami. BiH zmaga się z podobnymi problemami jak Macedonia. Te, które najtrudniej wyeliminować, to: przestępczość, korupcja, utrwalone, silne struktury mafijne. Również gospodarka jest rozwinięta zbyt słabo, by sprostać wymogom stawianym przez UE: wolnemu rynkowi, wolnej konkurencji, jednolitemu rynkowi. Zważywszy na te kwestie, można uznać za w pełni uzasadnioną opinię, że członkostwo w Unii Europejskiej jest dla tego państwa wciąż jeszcze odległą przyszłością. W prognozach - według mnie nadmiernie optymistycznych - szacuje się, że Bośnia i Hercegowina może stać się członkiem Unii Europejskiej w 2026 r. ${ }^{9}$ Nie będzie to jednak możliwe bez przeprowadzenia dogłębnych reform instytucjonalnych. Jest to bowiem państwo wyjątkowo trudno poddające się rygorom jakichkolwiek reform, szczególnie tych, których restrykcyjnie wymaga Unia Europejska.

\subsection{Republika Serbii}

Republika Serbii złożyła wniosek o członkostwo w Unii Europejskiej trzy lata po ogłoszeniu aktu niepodległości, 23 grudnia 2009 r. Negocjacje akcesyjne zostały rozpoczęte decyzją Rady Europejskiej w czerwcu 2013 r., co ocenia się jako wyraz uznania dla postępów Serbii w kwestii normalizacji stosunków z Kosowem. Rok wcześniej, 1 marca 2012 r., Serbia uzyskała oficjalny status kraju kandydującego, zaś 21 stycznia 2014 r. rozpoczęła negocjacje. Obecnie trwa screening ${ }^{10}$.

Republika Serbii jest w trakcie negocjacji przystąpienia do Unii Europejskiej, jednak wciąż jeszcze zgłaszane są pod jej adresem liczne zastrzeżenia. Najpoważniejszym jest nierozwiązana kwestia statusu Kosowa ${ }^{11}$. Tymczasem Unia warunkuje członkostwo Republiki Serbii uznaniem przez nią samodzielności Republiki Kosowa. Warto zauważyć, iż implementacja porozumienia zawartego przez Republikę Serbii z Republiką Kosowa w Brukseli 19 kwietnia 2013 r. może znacznie przyspieszyć członkostwo Republiki Serbii w UE. Ale kraj ten wciąż zmaga się z wieloma problemami: słabą gospodarką ${ }^{12}$,

9 Szerzej zob. P. Rosiak, Bośnia i Hercegowina: modelowy brak stabilności gospodarczej, [online] http:// forsal.pl/arykuly/1039610,bosnia-i-hercegowina-modelowy, 12 X 2017.

10 Procedura oceny państwa kandydującego do UE pod względem zgodności z prawem obowiązującym w Unii Europejskiej. Zob. Screening, [online] https://sjp.pwn.pl/sjp/screening;2574997.html, 23 III 2018.

11 M. Szpala, Serbia: kandydat do UE, Biuro Analiz Sejmowych, „Infos” 2008, nr 4, s. 3, [online] orka. sejm.opov.pl/WydBas.nfs/o/8DA6FFCACF30FC1CC1257F640045810C/\$fle/info, 23 III 2018. Zob. też: B. Bobev, Serbs in Kosovo as an Argument in the Process of Euro-Integration of the Two Balkan Countries, [w:] Republika Serbii. Aspekty polityki wewnętrznej i międzynarodowej, red. A. Jagełł-Szostak, Wrocław 2016, s. 151-163; E. Bujwid-Kurek, Republika Serbii w nowej przestrzeni ustrojowej. Dzieje, ustrój, konstytucja, Kraków 2012, passim.

12 M. Stamenović, B. Gulan, B. Dragaš, Srbija danas. Savremeni aspekti neoliberalizma, ekonomije, demografie, zdastva, bezbednosti i tranzicije, Novi Sad 2017. Zob. też: M. Stepič, Srpsko pitanije. Geopolitičko pitanije, Beograd 2004, s. 305-349. 
korupcją ${ }^{13}$, ubóstwem, którym dotknięte są szczególnie gminy serbskie w północnej części Kosowa, słabym przestrzeganiem prawa ${ }^{14}$, przestępczością, brakiem reformy sądownictwa, policji, administracji publicznej. Wydawać by się mogło, że balansująca między Federacją Rosyjską a Unią Europejską zmuszona do podjęcia decyzji Serbia wybierze kierunek prorosyjski, jednak - co potwierdza wypowiedź premier rządu Republiki Serbii Any Brnabić z 2017 r. - jeśli trzeba będzie wybierać, kierunek będzie unijny. Premier nie wykluczała również członkostwa Serbii w Unii Europejskiej już za cztery lata, tj. w 2021 r. $^{15}$, jednak - jak wynika z opinii Komisji Europejskiej z 6 lutego 2018 r. - data ta jest nierealna i systematycznie oddala się. Komisja jako najbardziej prawdopodobną datę wstąpienia Republiki Serbii do Unii Europejskiej prognozuje dopiero rok $2025^{16}$.

Trzeba pamiętać, że dotychczas spośród otwartych 12 rozdziałów akcesyjnych zamknięte zostały 2: rozdział 20 i rozdział 26 . Rozdział 20 dotyczy polityki w zakresie przedsiębiorstw i przemysłu, a jego zamknięcie wynikało ze zobowiązania Serbii do przygotowania i rozpoczęcia wprowadzania kompleksowej strategii rozwoju przemysłu wspieranego przez system parametryczny wyznaczony przez Unię Europejską. Rozdział 26 dotyczy zaś edukacji i kultury - Serbia została oceniona jako państwo dobrze przygotowane w obu dziedzinach i pod tym względem spełnia oczekiwania Unii Europejskiej ${ }^{17}$. Jednocześnie stwierdzono, że przez cały okres akcesyjny będzie trwał proces monitorowania postępów Serbii w dostosowaniu do przepisów unijnych ${ }^{18}$.

\subsection{Czarnogóra}

Podobnie jak Republika Serbii, w 2006 r. swoją niepodległość ogłosiła Czarnogóra. Już w grudniu 2009 r. złożyła ona wniosek o członkostwo w Unii Europejskiej. Zgodnie z istniejącą w UE procedurą oceniono, że państwo to osiągnęło niezbędny stopień zgodności z kryteriami stawianymi państwom członkowskim i spełniło priorytety Komisji Europejskiej. W grudniu 2010 r. Czarnogóra uzyskała status kraju kandydującego do UE. Układ o stabilizacji i stowarzyszeniu Unii Europejskiej z tym krajem obowiązuje od 2010 r.

13 S. Bolčić, Razaranje i rekonstitucija društva: Srbija na prelazu u XXI vek, Beograd 2013, s. 174- 185.

14 J. Trkulja, Nemoč prava. Pravno-politikološke rasprave, Beograd 2016, s. 132-140.

15 Polityka zagraniczna, [online] http:/balkanistyka.org/category/polityka-2/polityka-zagraniczna, 11 VII 2017.

16 Batkany Zachodnie...

17 Rada Unii Europejskiej, Piate ministerialne posiedzenie konferencji akcesyjnej z udziatem Serbii, Komunikat Prasowy 89/17, 27 II 2017, [online] www.consilium.europa.eu/pl/press/press-releases/2017/02/27/accession0conference, 23 III 2018.

18 Decyzja taka zapadła podczas spotkania w Luksemburgu 20 VI 2017 r. Brali w nim udział m.in.: wicepremier Malty Louis Grech; reprezentujący Komisję Europejską Johannes Hahn, komisarz ds. europejkkiej polityki sąsiedztwa i negocjacji rozszerzeniowej; delegat Republiki Serbii, minister bez teki ds. integracji europejskiej Jadranka Joksimović. Zob. Council of the EU, Sixth Meeting of the Accession Conference with Serbia at Ministerial Level Luxembourg, Komunikat Prasowy 384/17, 20 VI 2017, [online] www.consilium.europa.eu/pl/press-releases/2017/06/20/Serbia-6th-accesion, 23 III 2018. 
Aktualnie Czarnogóra jest w trakcie negocjacji przystąpienia do UE. W kontekście prowadzonych rozważań należy zwrócić uwagę, że to właśnie Czarnogóra, która rozpoczęła negocjacje akcesyjne 29 czerwca 2012 r., ma szanse wejść do Unii Europejskiej w najkrótszym czasie. Spośród wszystkich branych tu pod uwage państw pojugosłowiańskich wyróżnia się ona największym zdyscyplinowaniem, co pozwala jej na terminową realizację wszelkich wymagań stawianych przez UE. Opinia ta opiera się na ocenie stopnia zaawansowania prowadzonych negocjacji. Do końca grudnia 2016 r. otwarto aż 26 z łącznej liczby 35 rozdziałów negocjacyjnych ${ }^{19}$. Pół roku wcześniej, 30 czerwca 2015 r., podczas trzeciej sesji konferencji akcesyjnej w Brukseli, negocjatorzy ${ }^{20}$ uzgodnili otwarcie rozdziału 16 oraz rozdziału 30. Rozdział 16 dotyczący podatków szczegółowo precyzuje przepisy w obszarach wymagających dostosowania prawa Czarnogóry do prawa Unii Europejskiej, postępów w dziedzinie VAT, akcyzy i podatków bezpośrednich. W tym samym rozdziale jest mowa o zdolnościach administracyjnych i wymaganiach infrastruktury w centralnych i lokalnych urzędach skarbowych w celu egzekwowania przepisów podatkowych, pobierania podatków i kontrolowania podatników. Także w tym rozdziale poruszana jest kwestia przygotowania systemów informatycznych dla organów podatkowych i połączeń międzysystemowych dotyczących VAT (VIES) i akcyzy (EMCS), także tych umożliwiających wymianę informacji w dziedzinie podatków bezpośrednich ${ }^{21}$.

Na podkreślenie zasługuje fakt, że Czarnogóra, wywiązując się z nałożonych nań zobowiązań finansowych, aktywnie partycypuje w budżecie UE ${ }^{22}$. Należy też zauważyć, że od 5 czerwca 2017 r. Czarnogóra jest członkiem NATO, co - choć jeszcze nieformalnie - zbliża ją do państw unijnych o „podwójnym” członkostwie: w UE i w NATO. Komisja Europejska w wyrażonej 6 lutego 2018 r. opinii szacuje, że Czarnogóra, podobnie jak Republika Serbii, ma realne szanse na członkostwo w Unii w 2025 r. $^{23}$

\subsection{Republika Kosowa}

Republika Kosowa jako samodzielne państwo uznane przez większość państw członków UE także aspiruje do członkostwa w Unii Europejskiej. Pięć lat po ogłoszeniu przez Kosowo aktu niepodległości (17 lutego 2008 r.) Rada Europejska wyraziła zgodę na rozpoczęcie negocjacji w sprawie Układu o stabilizacji i stowarzyszeniu. I choć według Komisji Europejskiej Kosowo jest wyłącznie obszarem administracyjnym Serbii

19 Parlament Europejski, Noty faktograficzne o Unii Europejskiej. Batkany Zachodnie, [online] http:// www.europarl.europa.eu/atyourservice/pl/displayFtu.html?ftu, 12 VII 2017.

20 Unia Europejska reprezentowana była przez stałą przedstawicielkę Łotwy przy UE Ilze Juhansone, Czarnogórę reprezentowała Andrija Pejović, sekretarz stanu ds. europejskich, główna negocjatorka wejścia Czarnogóry do UE. Zob. Rada Unii Europejskiej, Czarnogóra i UE otwierają kolejne dwa rozdziaty negocjacyjne w procesie akcesyjnym, Komunikat Prasowy 159/15, 30 III 2015, [online] www. consilium.europa.eu/pl/press/press-releases/2015.03.03/montenegro-eu-op, 23 III 2018.

21 Tamże.

22 Co dzieje się w ramach programu Fiscalis 2020.

23. Batkany Zachodnie... 
pozostającym pod międzynarodowym nadzorem, to wcale nie przeszkodziło w negocjacjach, rozpoczętych 28 października 2013 r. ${ }^{24} 27$ października 2015 r. podpisano porozumienie ${ }^{25}$, które weszło w życie 1 kwietnia 2016 r. $^{26}$

Pamiętać też trzeba, że 6 października 2008 r., wkrótce po ogłoszeniu niepodległości przez Kosowo, w ramach pomocy finansowej podpisano Instrument for Pre-Accession Assistance (IPA) - umowę o dofinansowaniu rocznego programu dla Kosowa ${ }^{27}$. W związku z tym zostało ono zobowiązane do podjęcia działań w zakresie przestrzegania prawa, zwalczania przestępczości, w tym przestępczości zorganizowanej, zadbania o konserwację zabytków (głównie monasterów prawosławnych i mienia kulturowego). Fundusze te miały być także przeznaczone na wsparcie działalności niezależnych mass mediów, poprawę infrastruktury i oszczędne użytkowanie energii, w tym wdrożenie systemu energetycznych zasobów energii odnawialnej, usprawnienie gospodarki, szkolnictwa, rynku pracy i polityki zdrowotnej ${ }^{28}$.

Katalog najpilniejszych, wciąż wymagających rozwiązania problemów, z którymi bezwzględnie musi uporać się Republika Kosowa, jest bardzo obszerny. Pierwsze miejsce, podobnie jak w przypadku Serbii, zajmuje nierozwiązany, mimo zawartego w 2013 r. w Brukseli porozumienia, spór serbsko-kosowski o status Republiki Kosowa jako samodzielnego państwa. Inne kwestie, które oddalają ją od członkostwa w Unii Europejskiej, to m.in.: słaba gospodarka, silne struktury mafijne, oskarżenia o zbrodnie wojenne, brak instrumentów kontroli mniejszości serbskiej i romskiej, niszczenie zabytków kultury prawosławnej, brak reformy administracji, brak reformy sądownictwa odpowiadającej wymogom stawianym przez UE. Za jedną z podstawowych przeszkód dla członkostwa Republiki Kosowa w Unii uważa się brak oficjalnego uznania przez Unię Europejską jej niepodległości ${ }^{29}$. Republika Kosowa, podobnie jak Bośnia i Hercegowina, wciąż jeszcze ma status potencjalnego kandydata.

Spośród omawianych państw największe szanse na członkostwo w UE mają według Komisji Europejskiej Czarnogóra i Republika Serbii. Pozostałe: Republika Macedonii, Bośnia i Hercegowina oraz Republika Kosowa ciągle jeszcze pozostają na

24 Porozumienie o stabilizacji i stowarzyszeniu z Kosowem, tzw. formuta EK - only, zawarto w maju 2014 r. EU Starts the Stabilisation and Association Agreement Negotiations with Kosovo, [online] http://europa.eu/rapid/press-release_MEMO-13-938_en.htm?locale=en, 1 III 2016.

25 Stabilisation and Association Agreement between in European Union and Kosovo signed, [online] http:// www.consilium.europa.eu/en/press/press-releases/2015/10/27/kosovo-eu-stabilisation-association-agreement/, 1 III 2016.

26 Pomoc finansowa udzielona przez Komisję Europejską wyniosła 122,7 mln euro. Zob. Kosovo, [online] https://ec.europa.eu/neighbourhood-europa-enlargement/countries/detailed-country, 6 IV 2016.

27 Więcej zob. Kosovo (under UNSCR 1244) 2008 Progress Raport, Commission Staff Working Document, [online] https://ec.europa.eu/neighbourhood-enlargement/sites/ner/files/pdf/press_corner/ lecy-documents/raports_nov_2008/Kosovo_progrss_raport, 8 V 2018. munia) oficjalnie go nie uznały, zaś 2 (Grecja i Słowacja) nie wyraziły w tej sprawie oficjalnego stanowiska. 
etapie przygotowania i czekają w „blokach startowych” na przyznanie rozdziałów negocjacyjnych $^{30}$. Należy zauważyć, że wszystkie te państwa - bez względu na to, czy przyznano im już rozdziały negocjacyjne - korzystają z funduszy Unii Europejskiej oraz porad (konsultacji) dotyczących zawierania umów o stabilizacji i stowarzyszeniu, które mają im zapewnić otwarty dostęp do rynku wewnętrznego UE. Pamiętać też trzeba, że warunkiem sine qua non tego, by państwo zostało przyjęte do Unii Europejskiej, jest zgoda Parlamentu Europejskiego. Dnia 6 lutego 2018 r. Komisja Europejska opublikowała dokument strategiczny w sprawie rozszerzenia. Jej przedstawiciele, rozważając przyjęcie Czarnogóry i Serbii do Unii Europejskiej, dyskutowali z posłami o strategii podczas debaty plenarnej w Strasburgu. Posłowie z nieskrywanym zadowoleniem przyjęli decyzję o rozszerzeniu Unii, jednak zwracali uwagę na pilną potrzebę przeprowadzenia niezbędnych reform nie tylko w ich państwach, lecz także na obszarze całego regionu bałkańskiego ${ }^{31}$. Sprawozdawca ds. Serbii w Parlamencie Europejskim, niemiecki eurodeputowany David McAllister (Europejska Partia Ludowa, EPL) stwierdził: stabilność, dobrobyt i pokój na kontynencie można zapewnić tylko wtedy, gdy my, Unia Europejska, poprzemy te kraje, by sprostaty różnym wyzwaniom strukturalnym i pokonaty różne lokalne problemy ${ }^{32}$, a wypowiadający się w kwestii wstąpienia Czarnogóry do UE Charles Tannock (Europejscy Konserwatyści i Reformatorzy, EKR), sprawozdawca ds. Czarnogóry, zwrócił uwagę, że rok 2025 jest dość oddalony, ale nie możemy ignorować rosnacego sceptycyzmu w niektórych częściach Unii Europejskiej wobec wszystkich przysztych rozszerzeń, ze szczególnym niepokojem w kwestii korupcji i zorganizowanej przestępczości $i^{33}$.

\section{PODSUMOWANIE}

Odpowiadając na postawione pytania badawcze, można stwierdzić, że wszystkie brane pod uwagę w analizie państwa pojugosłowiańskie ubiegają się o członkostwo w Unii Europejskiej. Jednakże dopiero zaczynają one uczyć się „zachowań”, których wymaga od nich Unia. Najbardziej typowe i najczęściej powtarzające się w nich problemy są związane $\mathrm{z}$ ustanowieniem demokratycznego państwa prawnego, w tym przeprowadzenie reform: sądownictwa, policji, administracji państwowej. Wciąż jeszcze występują najtrudniejsze do wyeliminowania zjawiska: korupcji, przestępczości na szeroką skalę, w tym szczególnie niebezpiecznej przestępczości zorganizowanej. Dostrzegalną słabością jest też niewystarczająco rozwinięta gospodarka, wciąż nie dość dobrze przygotowana, by sprostać prywatyzacji, wolnemu rynkowi, wolnej konkurencji. Zainteresowanie Unii Europejskiej państwami mającymi trudności z przeprowadzeniem reform mogłoby zdumiewać, jednak wyjaśnia je troska o bezpieczeństwo w Europie. Nowe

\footnotetext{
Batkany Zachodnie...

Tamże.

32 Tamże.

33 Tamże.
} 
państwa bałkańskie, jak dowodzą wydarzenia z przeszłości, mogą stać się zarzewiem otwartych konfliktów zbrojnych, dlatego zainteresowanie Unii jest uzasadnione.

\section{BIBLIOGRAFIA}

Batkany Zachodnie: Kolejny kierunek rozszerzenia Unii Europejskiej?, [online] www.europarl. europa.eu/news/pl/headlins/world/20180126S5094113/ball.

Bolčić S., Razaranje i rekonstitucija društva: Srbija na prelazu u XXI vek, Beograd 2013.

Bujwid-Kurek E., „Nieunijne” państwa pojugostowiańskie w obliczu integrującej się Europy - uwag kilka, „Studia Politologiczne” 2018, vol. 47.

Bujwid-Kurek E., Serbia w nowej przestrzeni ustrojowej. Dzieje, ustrój, konstytucja, Kraków 2012.

Council of the EU, Sixth Meeting of the Accession Conference with Serbia at Ministerial level Luxembourg, Komunikat Prasowy 384/17, 20 VI 2017, [online] www.consilium.europa.eu/ $\mathrm{pl} /$ press-releases/2017/06/20/Serbia-6th-accesion.

EU Starts the Stabilisation and Association Agreement Negotiations with Kosovo, [online] http:// europa.eu/rapid/press-release_MEMO-13-938_en.htm?locale=en.

Komisja Europejska, 2009 - rok Batkanów Zachodnich, Bruksela, 5 XI 2008, IP/08/1638, [online] http://europa.eu/rapid/press-release_IP-08-1638_pl.htm.

Kosovo, [online] https://ec.europa.eu/neighbourhood-europa-enlargement/countries/detailedcountry.

Kosovo (under UNSCR 1244) 2008 Progress Report, Commission Staff Working Document, [online] https://ec.europa.eu/neighburhood-enlargement/sites/near/files/pdf/press_corner/ lecy-documments/reports_nov_2008/Kosovo_progrsee_raport.

Lopandić D., Kronja J., Regionalne inicijative i multilateralna saradnjana Balkanu, Beograd 2010.

Noty faktograficzne o Unii Europejskiej. Batkany Zachodnie, Parlament Europejski, [online] http://www.europarl.europa.eu/atyourservice/pl/displayFtu.html?ftu.

Podgórzańska R., Perspektywy integracji państw pojugostowiańskich z Unia Europejską, „Rocznik Integracji Europejskiej" 2010, nr 4.

Polityka zagraniczna, [online] http:/balkanistyka.org/category/polityka-2/polityka-zagra niczna.

Rada Unii Europejskiej, Czarnogóra i UE otwierają kolejne dwa rozdziaty negocjacyjne w procesie akcesyjnym, Komunikat Prasowy 159/15, 30 III 2015, [online] www.consilium.europa.eu/ $\mathrm{pl} /$ press/press-releases/2015.03.03/montenegro-eu-op.

Rada Unii Europejskiej, Piate ministerialne posiedzenie konferencji akcesyjnej z udziatem Serbii, Komunikat Prasowy 89/17, 27 II 2017, [online] www.consilium.europa.eu/pl/press/ press-releases/2017/02/27/accession0conference.

Republika Serbii. Aspekty polityki wewnętrznej i międzynarodowej, red. A. Jagiełło-Szostak, Wroclaw 2016.

Rosiak P., Bośnia i Hercegowina: modelowy brak stabilności gospodarczej, [online] http://forsal. $\mathrm{pl} /$ arykuly/1039610,bosnia-i-hercegowina-modelowy. 
Screening, [online] https://sjp.pwn.pl/sjp/screening;2574997.html.

Stabilisation and Association Agreement between in European Union and Kosovo Signed, [online] http://www.consilium.europa.eu/en/press/press-releases/2015/10/27/kosovo-eustabilisation-association-agreement/.

Stamenović M., Gulan B., Dragaš B., Srbija danas. Savremeni aspekti neoliberalizma, ekonomije, demografie, zdastva, bezbednosti i tranzicije, Novi Sad 2017.

Stepič M., Srpsko pitanije. Geopolitičko pitanije, Beograd 2004.

Szpala M., Serbia: kandydat do UE, Biuro Analiz Sejmowych, „Infos” 2008, nr 4, [online] orka. sejm.opov.pl/WydBas.nfs/o/8DA6FFCACF30FC1CC1257F640045810C/\$fle/info.

Traktat o Unii Europejskiej, stan prawny aktualny na 9 V 2018, Dz.U. UE 2004, 90.864/30, [online] www.arslage.pl/tratkat-o-unii-europejskiej/k78.

Trkulja J., Nemoč prava. Pravno-politikološke rasprave, Beograd 2016.

Welcome Europe, [online] https://www.welcomeurope.com.

Wybranowski D., Bośnia i Hercegowina wobec Unii Europejskiej - trudna droga ku stowarzyszeniu. Problemy i wyzwania polityki UE na Batkanach Zachodnich na poczattu XXI wieku, „Wrocławskie Studia Politologiczne” 2009, nr 10.

Zawistowska R., Miejsce Batkanów Zachodnich w polityce Unii Europejskiej, „Annales Universitatis Paedagogicae Cracoviensis. Studia Politologica” 2012, nr 7.

Prof. dr hab. Ewa BUJWID-KUREK, politolog, pracownik naukowo-dydaktyczny w Instytucie Nauk Politycznych i Stosunków Międzynarodowych Uniwersytetu Jagiellońskiego, w którym pełni funkcję kierownika Katedry Współczesnych Transformacji Politycznych. Obecnie jest także prodziekanem ds. nauki na Wydziale Studiów Międzynarodowych i Politycznych UJ. Jej główne zainteresowania naukowe koncentrują się wokół współczesnej problematyki państw bałkańskich ze szczególnym uwzględnieniem państw powstałych w wyniku dekompozycji federacji jugosłowiańskiej u schyłku XX w. Wśród jej naukowych zainteresowań są też systemy polityczne państw znajdujących się w procesie transformacji ustrojowej, w tym polski system polityczny. Jest autorką kilku monografii z tego zakresu, m.in.: Państwa pojugostowiańskie. Szkice politologiczne (2008); Serbia w nowej przestrzeni ustrojowej. Dzieje, ustrój, konstytucja (2012); Transformacja ustroju politycznego wybranych panstw Europy Środkowej i Potudniowo-Wschodniej (2015, współautorka); III Rzeczpospolita Polska 1990-2016. Opinie, dylematy, kontrowersje (2016, współredakcja), a także licznych artykułów naukowych. 